\title{
Effect of Rice Husk Ash on the Shear Strength Parameters of Silty Sand
}

\author{
Anurag Gangwar ${ }^{1}$, Anoopsingh Chandel ${ }^{2}$ \\ ${ }^{1}$ Assistant Professor, Civil Engineering Department, BIET Lucknow - 226201 (U. P.), India \\ ${ }^{2}$ Assistant Professor, Civil Engineering Department, SMSIT Lucknow - 226501 (U. P.), India
}

\begin{abstract}
It is a known truth that sand possesses zero cohesion. As a consequence, the resulting shear strength parameters are of poor nature. If sand is to be used for the purpose of embankments such as in desert areas of Thar and Katchh, it is inevitable that the shear strength parameters of a sandy soil should be improvised. The present study aims at improving the shear strength parameters of chosen soil sample i.e. silty sand with the help of a natural waste (rice husk ash). Shear strength parameters are evaluated using direct shear test. Also with the addition of varying proportions of rice husk ash (RHA), CBR test are carried as a check parameter. The detailed study and discussions can be described as below.
\end{abstract}

Keywords: Silty sand, Rice husk ash (RHA), Particle size distribution, shear strength parameters, Cohesion (c), angle of internal friction (ф), Direct shear test, CBR test.

\section{Introduction}

Soil is one of the most abundant naturally occurring construction and foundation material. Generally, the suitability of a soil for a particular use should be determined based on its engineering characteristics. In most cases, soils need to be 'improved' in order to meet the geotechnical characteristics/properties required for a specific project. Soil improvement could be either by modification or stabilization, or even both. In common practice improvement of soil using conventional additive materials such as cement and lime that has kept the cost of construction financially high. The price of these materials has dramatically increased due to high demand since 1970s. However, in recent years, the use of various waste products in civil engineering construction has gained considerable attention in view of shortage and high cost of convectional construction materials, increasing cost of waste disposal, and environmental constraints. Rice husk is one of the waste products that have been mentioned with potential to be used for stabilization of soil for road construction. When burnt, the resulting Rice Husk Ash (RHA) contains high percentage of siliceous compounds, making it an excellent material for road construction. In the present study, RHA in different proportions is added to the sandy soil followed by direct shear test and CBR test.

\section{Literature Review}

Briefing by variousresearchers that have worked using RHA with different types of soil are as follows:

Rao et.al (2012) conducted study on improving the properties of expansive soil with help of ferric chloride and RHA. It was seen that decreases in liquid limit by $26 \%$ with the addition of $8 \%$ RHA and $1 \%$ Ferric chloride and swelling pressure reduced by $50 \%$ and increased UCS value $57 \%$ after 28 days curing.

Grytan et.al (2012) conducted studies on geotechnical properties of soil in stabilizing by using RHA and conducted various experiment for workability, strength, compressibility and compaction characteristic. Due to addition of RHA swelling index and compressibility is reduced. At $10 \%$ of RHA UCS and direct shear strength is optimised.

Subbarao et al., (2011) conducted study on Industrial Wastes in soil. It enhanced the geotechnical properties of soil replaced with wastes having pozzolanic properties like RHA and Fly Ash. 2\%, 4\%, and 6\% RHA of soil weight is used in soil sample. Using $4 \%$ RHA and Fly Ash is not giving much improvement in soil hence accelerator like lime is used with RHA and Fly Ash is used and optimum result is obtained.

Akshaya et al. (2010) conducted study on effect of RHA and marble dust on expansive soil. This study represents the test results of marble dust on strength and durability of soil with optimum percentage of RHA. For best stabilization is found on optimum proportion of soil RHA and Marble dust 70:10:20.

Aihassan Musa (2008) conducted experiment RHA and cement with soil. Using $2 \%$ to $8 \%$ cement by weight of soil for compaction, CBR, UCS characteristic. It is seen that increases OMC with decrement in dry density. Also improvement in CBR and UCS with increases RHA. Maximum UCS is obtained on $6 \%$ to $8 \%$ RHA.

\section{Materials and its Properties}

Two materials were used in the study namely Soil, Rice husk ash (RHA). Their properties are as follows.

The soil sample (sand) was collected from a trader at Sultanpur city and was tested in geotechnical laboratory, Civil Engineering Department, Kamla Nehru Institute of Technology, Sultanpur. The soil sample properties can be briefed in the tabular manner as below: 


\section{International Journal of Science and Research (IJSR) \\ ISSN (Online): 2319-7064 \\ Index Copernicus Value (2015): 78.96 | Impact Factor (2015): 6.391}

Table 1: Geotechnical properties of plain soil

\begin{tabular}{|c|c|c|}
\hline S. No. & Parameters & Results \\
\hline 1. & Specific Gravity & 2.55 \\
\hline 2. & Liquid Limit & $9 \%$ \\
\hline 3. & Plastic Limit & Non Plastic \\
\hline 4. & Sand Content & $81.65 \%$ \\
\hline 5. & Silt Content & $13.19 \%$ \\
\hline 6. & Clay Content & $5.16 \%$ \\
\hline 7. & Indian Soil Classification & SM (silty sand) \\
\hline 8. & Optimum Moisture content & $14.35 \%$ \\
\hline 9. & Maximum Dry Density & $1.75 \mathrm{~g} / \mathrm{cc}$ \\
\hline 10. & CBR & 6.14 \\
\hline 11. & Direct Shear Result & $\mathrm{c}=9.291 \mathrm{kN} / \mathrm{m}^{2} \phi=29^{\circ}$ \\
\hline
\end{tabular}

The particle size distribution curve can be shown as below:

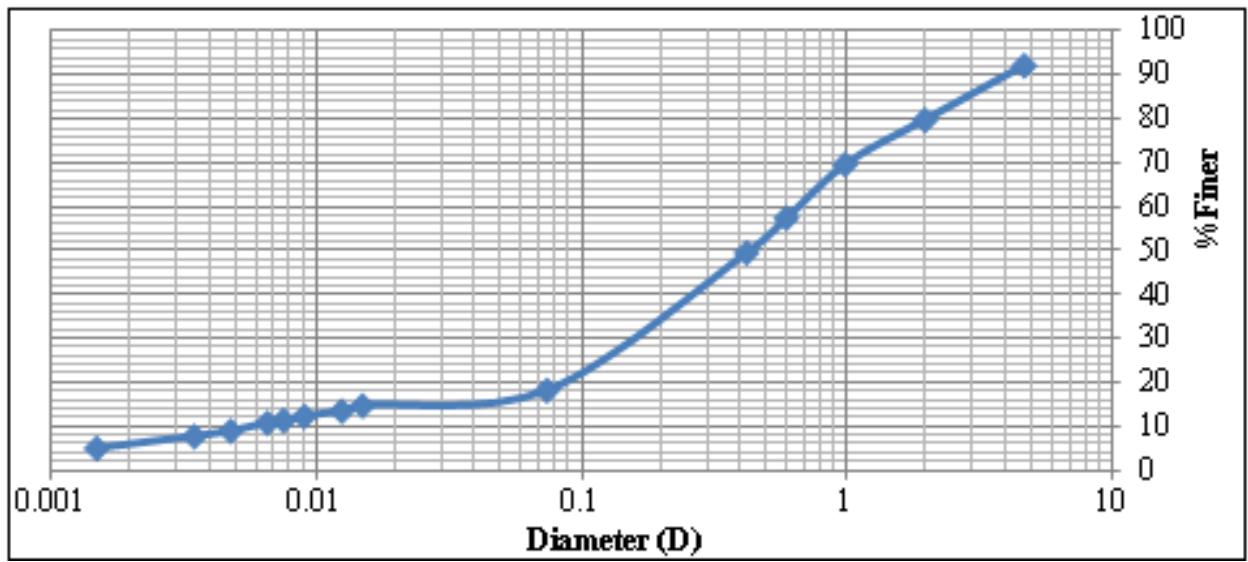

Figure 1: Graph for particle size analysis of plain soil

Rice husk is by product obtained during milling of rice. Burning of the rice husk in a kiln produces rice husk ash (RHA). The main component of the rice husk ash is silica, which is the element that governs the reactivity of the ash. A too high temperature would transform amorphous silica to crystalline silica, which would reduce the reactivity. The suggested burning process in literatures available is 2 hours at $500^{\circ} \mathrm{C}$. Literatures also suggest that RHA possesses pozzolanic properties. Few physical and chemical properties of rice husk ash can be briefed as below:

Table 2: Physical properties of rice husk ash

\begin{tabular}{|c|c|c|}
\hline Sr. No. & Properties & Values \\
\hline 1 & Sp. Gravity & 02.01 \\
\hline 2 & \% Gravel & 00.00 \\
\hline 3 & \% Sand & 43.60 \\
\hline 4 & \% Silt and Clay & 56.40 \\
\hline
\end{tabular}

Table 3: Chemical properties of rice husk ash

\begin{tabular}{|c|c|c|}
\hline Sr. No. & Constituents & Composition \\
\hline 1 & $\mathrm{SiO}_{2}$ & $86.00 \%$ \\
\hline 2 & $\mathrm{Al}_{2} \mathrm{O}_{3}$ & $02.60 \%$ \\
\hline 3 & $\mathrm{Fe}_{2} \mathrm{O}_{3}$ & $01.80 \%$ \\
\hline 4 & $\mathrm{CaO}$ & $03.60 \%$ \\
\hline 5 & $\mathrm{MgO}$ & $00.27 \%$ \\
\hline
\end{tabular}

\section{Test Methodology}

The effect of rice husk ash on the $\mathrm{c}-\phi$ values of soil sample has been studied in this study keeping in view that along with the increase in shear strength, the compression strength remain unaltered. Based on several literatures available, a series of tests has been decided to be performed on the different soil: rice husk ash (RHA) mixes with varying proportions of RHA. The different proportions proposed in this work are $5 \%, 8 \%, 11 \%$ and $14 \%$ w/w respectively.

Mix proportions adopted:

1) Soil: RHA = 95\%: $05 \%$

2) Soil: RHA $=92 \%: 08 \%$

3) Soil: RHA $=89 \%: 11 \%$

4) Soil: RHA $=86 \%: 14 \%$

The tests proposed on the different mixes are as under:

1) Proctor Compaction Test as per IS: 2720 (Part-8) - 1983

2) California Bearing Ratio (CBR) test as per IS: 2720 (Part-16) - 1987

3) Direct Shear Test as per IS: 2720 (Part-13) - 1986

\section{Results and Discussions}

The results of the test series performed on the different proposed soil mixes can be briefed as below: 


\section{International Journal of Science and Research (IJSR) \\ ISSN (Online): 2319-7064}

Index Copernicus Value (2015): 78.96 | Impact Factor (2015): 6.391

Table 4: Effect of RHA on soil samples

\begin{tabular}{|c|c|c|c|c|c|}
\hline Properties & $\begin{array}{c}\text { Plain Soil } \\
(100 \% \text { S:00\%RHA) }\end{array}$ & $\begin{array}{c}\text { Soil + 5\% RHA } \\
(95 \% \text { S:05\% RHA })\end{array}$ & $\begin{array}{c}\text { Soil + 8\% RHA } \\
(92 \% \text { S:08\%RHA })\end{array}$ & $\begin{array}{c}\text { Soil + } 11 \% \text { RHA } \\
(89 \% \text { S: } 11 \% \text { RHA })\end{array}$ & $\begin{array}{c}\text { Soil + 14\% RHA } \\
(86 \% \text { S: } 14 \% \text { RHA })\end{array}$ \\
\hline OMC (\%) & 14.35 & 14.70 & 15.17 & 15.58 & 15.66 \\
\hline MDD (g/cc) & 1.75 & 1.73 & 1.71 & 1.70 & 1.68 \\
\hline Cohesion $\mathrm{C}$ in $\mathrm{kN} / \mathrm{m}^{2}$ & 9.21 & 19.44 & 22.11 & 25.22 & 27.01 \\
\hline $\begin{array}{c}\text { Angle of Internal friction } \phi \text { in } \\
\text { degree }\end{array}$ & 29.0 & 27.5 & 24.0 & 23.5 & 20.5 \\
\hline CBR value & 6.14 & 7.63 & 8.37 & 9.67 & 9.30 \\
\hline
\end{tabular}

It can be clearly seen that maximum value of cohesion is obtained for $14 \%$ addition of RHA. But maximum CBR value is achieved at $11 \%$ addition of RHA. Further addition of RHA follows the fall in CBR value which is not desirable. Also, it can be observed that the OMC value is continuously rising along with a continuous declination in MDD results. The phenomena of continuous rise in the OMC as well as cohesion may be attributed to the continuous increase in \% RHA possessing more of finer grains particles.
Certain relations can be obtained and graphs can be plotted accordingly based on the following results available such as:

1) Change in OMC and MDD with addition of RHA to the soil sample

2) Change in cohesion and angle of internal friction with addition of RHA to the soil sample

3) Change in CBR value with addition of RHA to the soil sample

The graphs for the above relations are shown below:

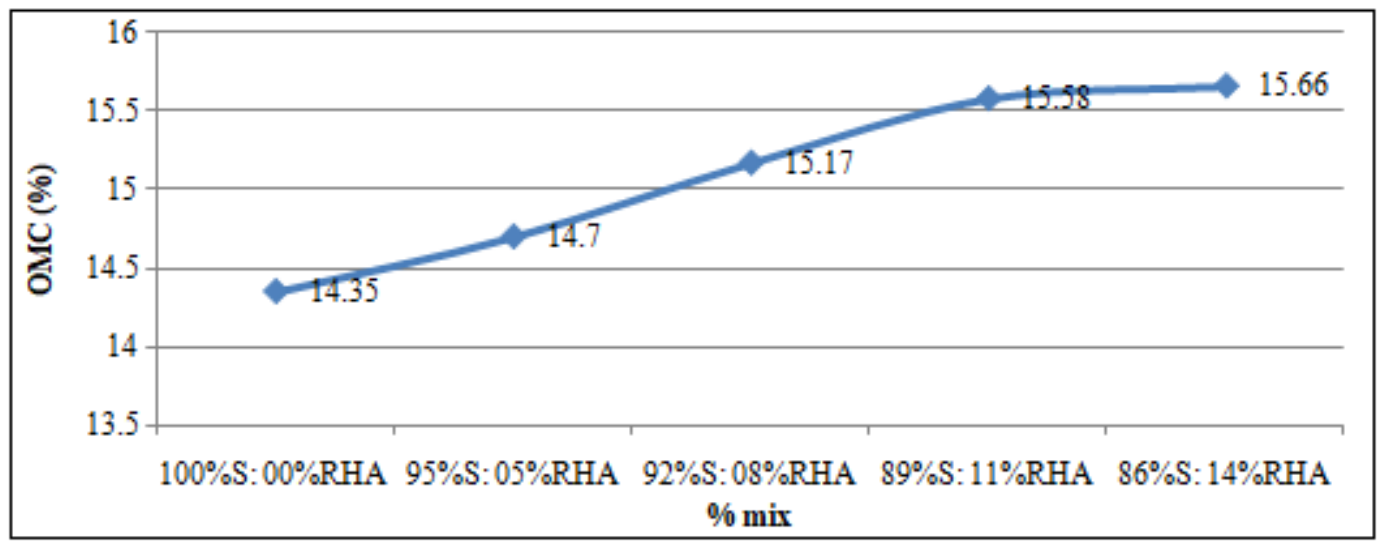

Figure 2: Change in OMC with percentage change of RHA

The continuous increase in the OMC value can be seen from the above graph with maximum value of $15.66 \%$ for $14 \%$ addition of RHA.

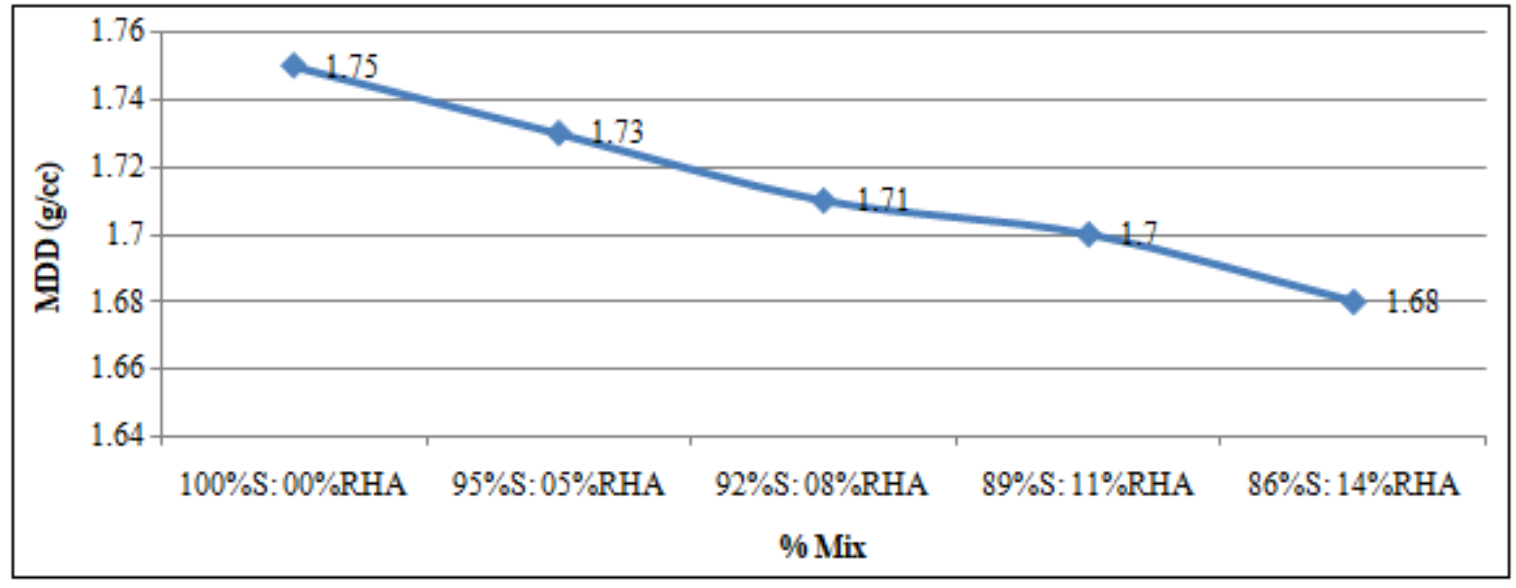

Figure 3: Change in MDD with percentage change of RHA

The continuous decrease in the MDD value can be seen from the above graph with minimum value of $1.68 \mathrm{~g} / \mathrm{cc}$ for $14 \%$ addition of RHA. 
International Journal of Science and Research (IJSR)

ISSN (Online): 2319-7064

Index Copernicus Value (2015): 78.96 | Impact Factor (2015): 6.391

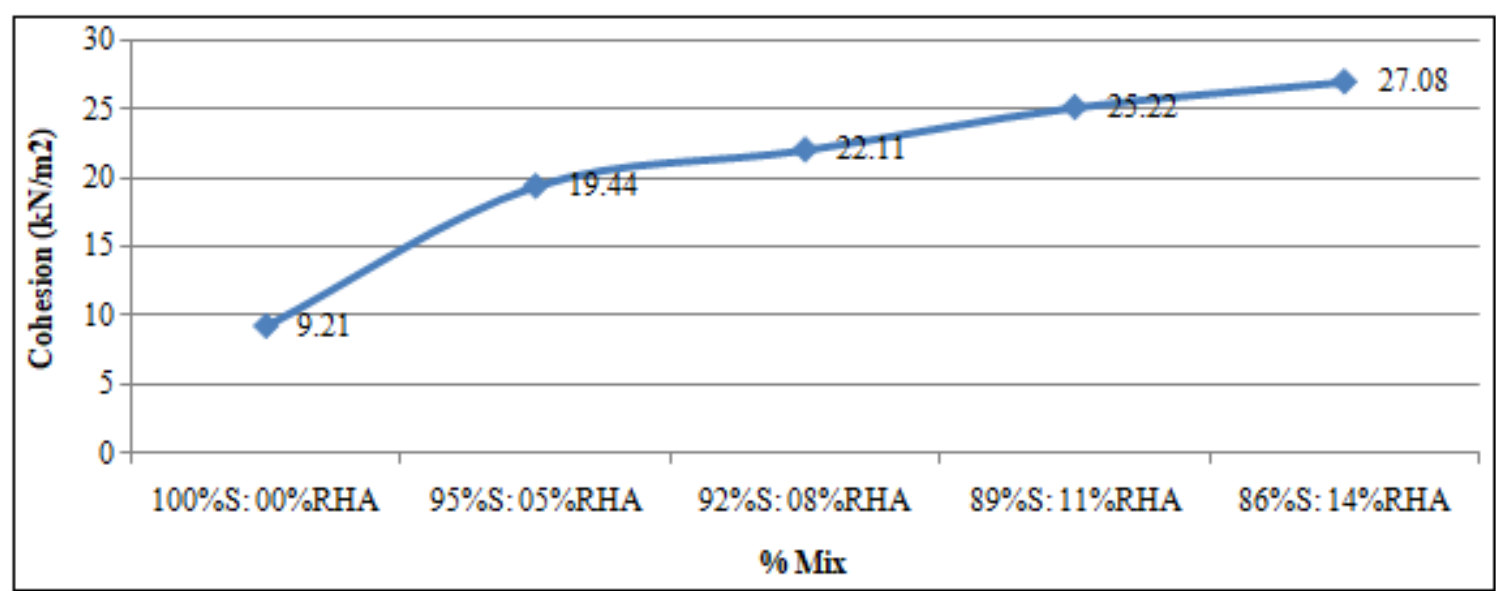

Figure 4: Change in cohesion with percentage change of RHA

The continuous increase in the cohesion value can be seen from the above graph with maximum value of $27.08 \mathrm{kN} / \mathrm{m}^{2}$ for $14 \%$ addition of RHA.

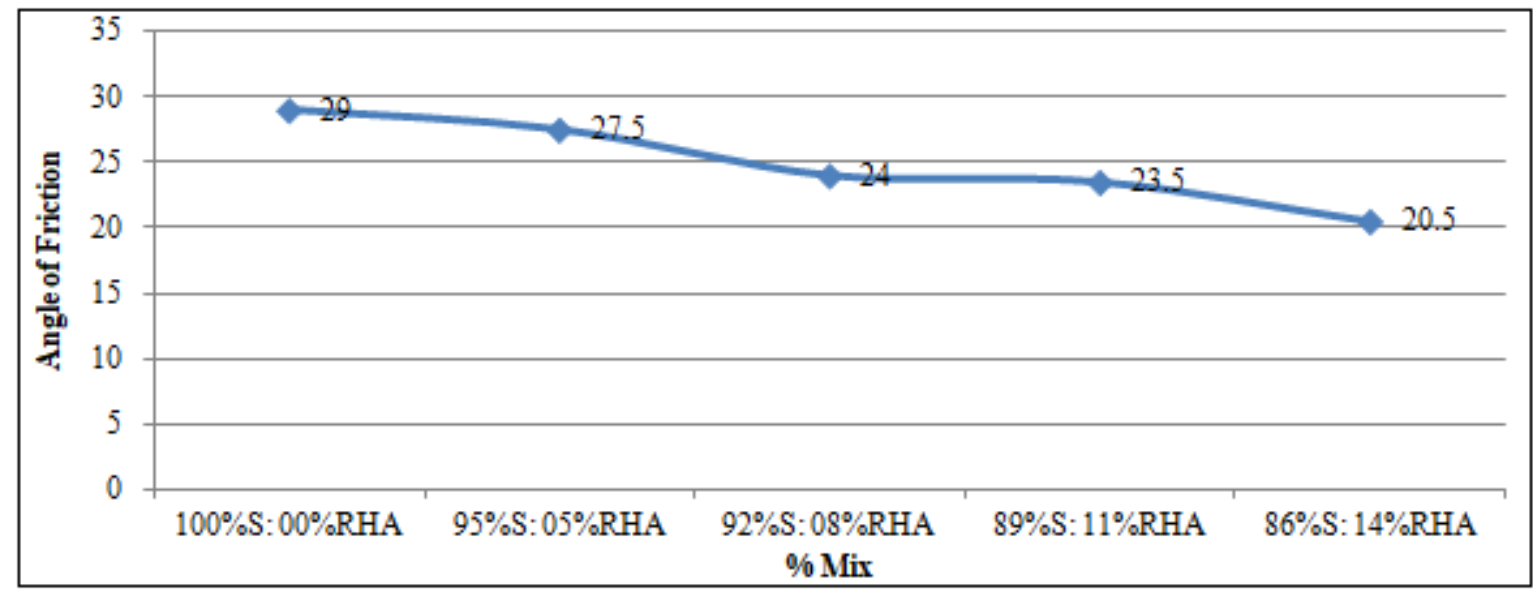

Figure 5: Change in angle of internal friction with percentage change of RHA

The gradual decrease in the angle of internal friction can be seen from the above graph with minimum value of $20.5^{\circ}$ for $14 \%$ addition of RHA.

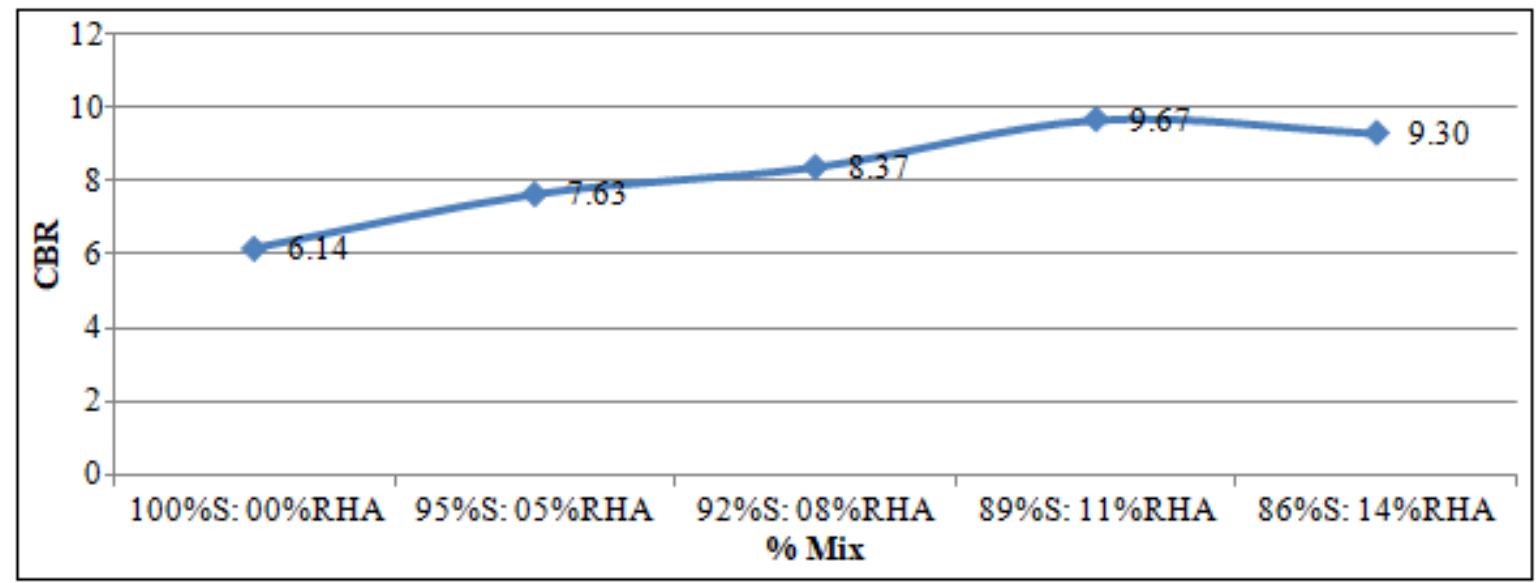

Figure 6: Change in CBR value with percentage change of RHA

The maximum value of $\mathrm{CBR}$ was achieved for $11 \%$ addition of RHA, further addition of RHA shows fall in the CBR value.

\section{Conclusions}

Following conclusions can be drawn from the study:
1) The optimum percentage of RHA for stabilization of soil was found out to be $11 \%$.

2) With increase in RHA content, MDD goes on decreasing and $\mathrm{OMC}$ goes on increasing.

3) From the results of direct shear, Cohesion increases with increase of the RHA content while Angle of friction decreases with increase in the value of RHA content.

Volume 6 Issue 7, July 2017 www.ijsr.net 


\section{International Journal of Science and Research (IJSR) \\ ISSN (Online): 2319-7064}

Index Copernicus Value (2015): 78.96 | Impact Factor (2015): 6.391

Cohesion increases continuously with addition of $0 \%$ to $14 \%$ RHA, but the CBR value increases only up to $11 \%$ addition of RHA content. Further addition of RHA decreases the CBR value of soil

4) Thus, best results for the purpose of stabilization can be achieved for the proportion of $89 \%$ S: $11 \%$ RHA.

\section{References}

[1] Arora K. R., Soil Mechanics and Foundation Engineering (Geotechnical Engineering), Standard Publishers Distributors, Delhi, India, 2008.

[2] Wirth, K., M. College, and A. Barth. X-ray Fluorescence (XRF). May 29, 2012 "Geochemical Instrumentation and Analysis"

[3] Lung Hwang, Chao, and Satish Chandra. "The Use of Rice Husk Ash" in Concrete.Tech.

[4] Dr. D. KoteswaraRao, G.V.V. RameswaraRao, P.R.T. Pranav. "A Laboratory Study on the effect of Rice Husk Ash \& Lime on the Properties of Marine Clay"

[5] Alhassan, M., (2008) "Potentials of rice husk ash for stabilization" AU Journal of Technology.

[6] By Grytan Sarkar, Md. Rafiqul Islam, Dr. Muhammed Alamgir, Dr. Md.Rokonuzzaman. "Interpretation of Rice Husk Ash on Geotechnical Properties of Cohesive Soil"

[7] Into Dutch soils, E.a.S. Planning, Editor April 2010, Ministerie van VROM

[8] Fattah, M.Y., F.H. Rahil and K.Y.H. Al-Soudany, (2011) "Improvement of clayey soil characteristics using rice husk ash" Journal of Civil Engineering and Urbanism.

[9] Anoopsingh Chandel et. al. (2017) "Utilisation of Fly Ash and Coir Geonets in Improving the Geotechnical Properties of Clayey Soil" International Journal of Engineering Research \& Technology ISSN 2278-0181, Volume 6, Issue 05, May 2017, pp 29-38, www.ijert.org

[10] Muntohar, A. S. and Hantoro, G., (2000) "Influence of Rice Husk Ash and lime on engineering properties of a clayey subgrade" Electronic Journal of Geotechnical engineering .

[11] Anoopsingh Chandel et. al. (2016) "Permeability characteristics of clayey soil added with fly ash" Proceedings of International Conference on Emerging Trends in Civil Engineering (ICETCE-2016), ISBN: $978-93-86256-07-2$, October $21^{\text {st }}-22^{\text {nd }}, 2016$, pp $207-$ 209.

[12] Basha, A. M., Hashim, R. and Muntohar, A. S., (2003) "Effect of cement ricehusk ash on the plasticity and compaction of soil"

[13] Yamamoto, Y. and S.M. Lakho, (1982) "Production andutilization of rice husk ash as a substitute for cement" Proceedings of the Japanese Society of Civil Engineers.

[14]Zhang, M.H. and V.M. Malhotra, (1996) "High performance concrete incorporating rice husk ash as a supplementary cementing material" ACI Material Journal.

[15] Sivakumar, G. and R. Ravibaskar, (2009) "Investigation on hydration properties of the rice husk ash cementusing FTIR and SEM" Applied Physics Research.
[16] Anoopsingh Chandel et. al. (2016) "Comparative Study of Various Soils Upon Addition of Different Materials on the Basis of Hydraulic Conductivity Parameter" International Journal of Engineering Research \& Technology ISSN 2278-0181, Volume 5, Issue 05, pp 107-111.

[17] Abu Bakar, B.H., R. Putrajaya and H. Abdulaziz, (2009) "Malaysian Rice Husk Ash Improving the durability and corrosion resistance of concrete"

[18] Chopra, S.K., S.C. Ahluwalian and S. Laxmi, (1981) "Technology and manufacture of rice-husk ashmasonry (RHAM) cement" Proceedings of ESCAP/RCTT Workshop on Rice Husk Ash Cement,New Delhi.

[19] Ramadhansyah, P.J., A.W. Mahyun, M.Z. Salwa, B.H. Abu Bakar, M.A. Megat Johari and Wan M.H. Ibrahim, (2012) "Thermal analysis and pozzolanic index of rice husk ash at different grinding time" International Conference on Advances Science and Contemporary Engineering 2012.

[20] Muntohar, A.S., (2002) "Utilization of uncontrolled burnt rice husk ash in soil improvement"

[21]Zhang, M.H. and V.M. Malhotra, (1996). "High performance concrete incorporating rice husk ash as a supplementary cementing material" 